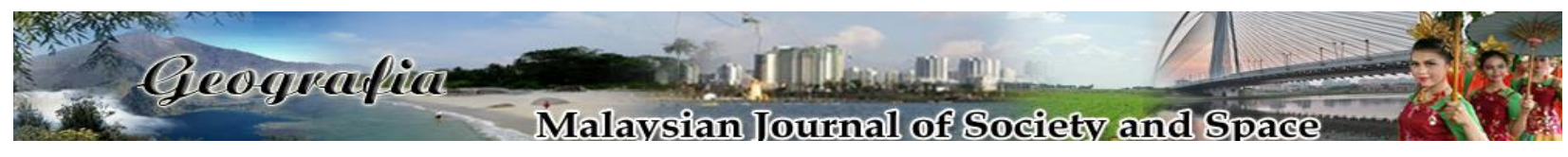

\title{
Seeking for sustainability: Actor's perspective on the Malaysian Sustainable Palm Oil Certification Scheme (MSPO)
}

\author{
Siti Rahyla Rahmat ${ }^{1}$, Suziana Mat Yasin ${ }^{1}$, Mohamad Fadhli Mad’ Atari², Azmil Tayeb ${ }^{1}$ \\ ${ }^{1}$ School of Social Sciences, Universiti Sains Malaysia \\ ${ }^{2}$ School of Biological Sciences, Universiti Sains Malaysia \\ Correspondence: Siti Rahyla Rahmat (email: rahyla@usm.my)
}

Received: 14 September 2020; Accepted: 04 May 2021; Published: 29 May 2021

\begin{abstract}
The Malaysian government established the Malaysian Sustainable Palm Oil (MSPO) certification primarily as a response to critics against the Roundtable on Sustainable Palm Oil (RSPO), chief among which is to urge the Malaysian government to play a more proactive role in protecting local palm oil producers. The aim of this study is threefold: (1) to identify why the Malaysian government creates MSPO; (2) to understand how Malaysian actors push for the MSPO; and (3) to investigate the current state of MSPO. We conducted nine expert interviews and four in-depth interviews with oil palm small holders. The study finds that the policy regarding palm oil in Malaysia is predominantly top-down in nature. The study concludes that the establishment and implementation of local palm oil certification standard as an alternative to the RSPO is not as straight-forward and more awareness among the smallholders on the importance of getting certified by MSPO is crucial. MSPO may establish a more effective and clearer line of communication between the federal government and the oil palm producers at the local level specifically small holders. The federal government, state agencies and MPOB needs to create awareness among the smallholders on the importance of getting certified by MSPO.
\end{abstract}

Keywords: Actors, governance, MSPO, palm oil, perspective, sustainability

\section{Introduction}

The Roundtable on Sustainable Palm Oil (RSPO), which was established in 2004, is a globallyaccepted certification used by the palm oil industry to promote sustainable growth and production. The certification is the result of the pressures exerted by Western countries especially the European Union to make palm oil production more environmentally and workers friendly. While getting RSPO certification is not a problem for major palm oil producers, it is not the case for small and medium sized palm oil producers, namely due to its prohibitive costs and onerous requirements. Therefore, as an alternative, the Malaysian government established the Malaysian Sustainable 
Palm Oil (MSPO) in 2014 to help small and medium sized palm oil producers to market their products abroad. In other words, the creation of MSPO is in a way a response to RSPO, which is to urge the Malaysian government to play a more proactive role in protecting local palm oil producers. The main focus of this article then is to look at the viability and implementation of MSPO especially in ways that it affects oil palm smallholders in Malaysia.

By 2018, the planted area for oil palm was 5.85 million hectares (MPOB, 2019). In the Malaysian palm oil industry, large private estates are pivotal actors in the upstream part of supply chains (comprising of $61 \%$ of the total plantation areas). As depicted in Figure 1, these are followed by plantations owned by Federal Land Development Authority (FELDA) (12\%), independent smallholders (17\%) with Federal Land Consolidation and Rehabilitation Authority (FELCRA) (3\%) and Rubber Industry Smallholders Development Authority (RISDA) (1\%), and state-owned plantations under Government Linked Companies (GLC) that represent the remaining $6 \%$ (MPOB, 2019). Independent small holders constitute quite a large proportion of the industry but they have different systems and approaches to farm management.

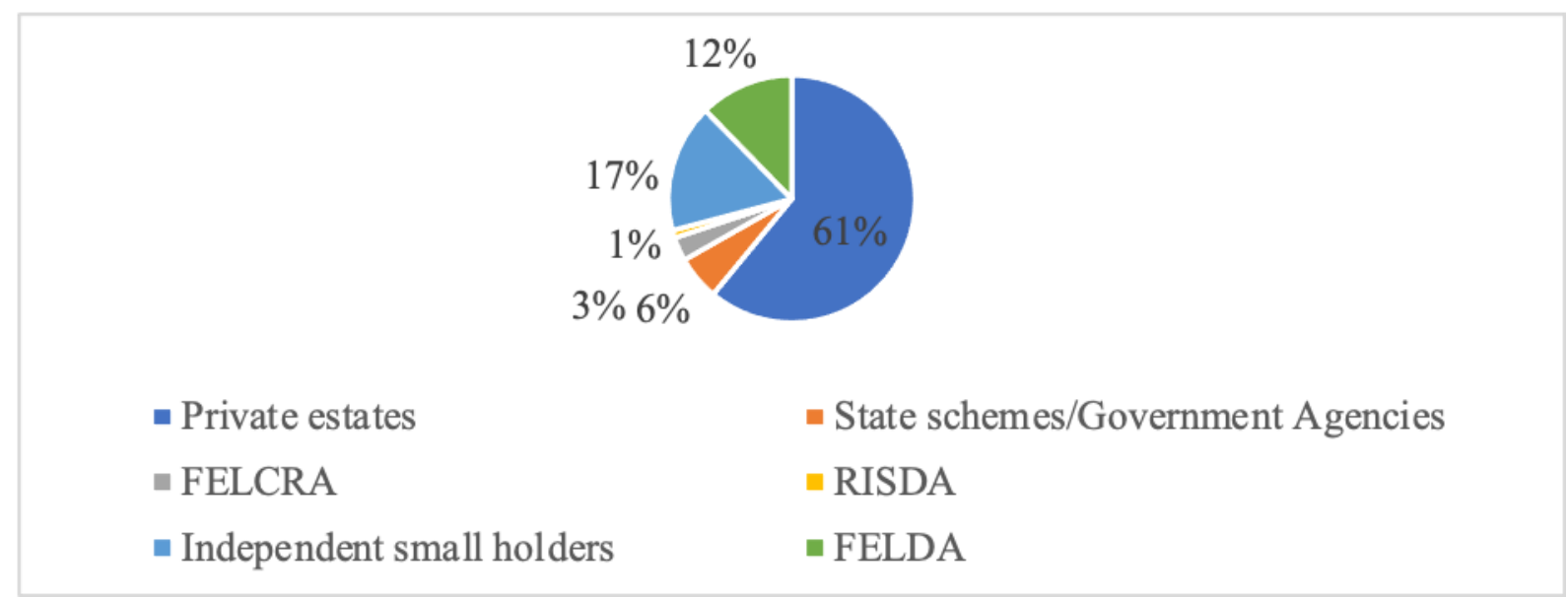

Source: Adapted from MPOB, 2019

Figure 1. Oil Palm Planted Area by Category, 2018

Malaysian palm oil industry is a major contributor to the agriculture sector's GDP at $46.6 \%$. Malaysia produces $39 \%$ of the world's palm oil production and $44 \%$ of world export (MPOC, 2019). In 2017, the total planted area in Malaysia was 5.74 million hectares and out of these 1.15 million hectares were RSPO and MSPO certified. For national sustainable initiative, Malaysia has introduced the MSPO and its compliance is mandatory for all players in the industry by December 2019. As for the RSPO, only $20 \%$ of Malaysian palm oil industry players have complied with this standard. The establishment of MSPO is seen as a response of Malaysian actors towards the debate related to RSPO. Therefore, this study's objectives are: (1) To identify why the MSPO was established; (2) To understand how Malaysian actors push for the MSPO; (3) To investigate what does the MSPO look like on the ground at the present time.

This paper first discusses the comparison between MSPO and RSPO and why the MSPO is introduced despite the implementation of the RSPO as an international certification scheme. Finally, the paper presents findings from in-depth interviews and content analysis and argues that the heavily top-down nature of the federal government's policy-making regarding palm oil poses detrimental effects on other actors in this industry. 


\section{Literature review}

\section{Actors in the Malaysian palm oil industry}

The palm oil industry in Malaysia begins at the upstream part of the chain that consists of nurseries, growers, and fruit collection centres. Two types of actors, extraction mills and oil refineries, constitute the processing segments of the chain. They are followed by the downstream part of the chain that consists of palm oil dealers and exporters.

There are two types of smallholders at the upstream level of the Malaysian oil palm supply chain: organized and unorganized smallholders. The organized smallholders are participants under Federal Land Development (FELDA), Federal Land Consolidation and Rehabilitation Authority (FELCRA), Rubber Industry Smallholders Development Authority (RISDA) and others, while independent smallholders are ones who operate outside of these settlement scheme. The yield of fresh fruit bunches (FFB) for independent smallholders are the lowest when compared to other sectors due to their inefficiencies such as using poor quality seedlings, late replanting old oil palm trees, harvesting unripe palm fruits, and poor data management practices (Rahman et al. 2008). However, some independent smallholders do gain benefits from MPOB replanting programme. NKEA report (2012) shows a reduction of areas planted with oil palms above the age of 25 from $7.49 \%$ (2008) to $7.15 \%$ (2012) of the total planted area.

\section{Institutional aspect and sustainability issues}

Studies on institutional aspects of palm oil industry, include business and civil society actors from the North set up the RSPO and RTRS as global private partnerships to curb deforestation and to promote sustainable production of palm oil or soy in the South. Some countries such as Indonesia and Brazil have come out with their own national initiatives for sustainable palm oil industry. In Indonesia, Chao (2019) has revealed that although there are efforts to implement sustainable oil palm cultivation, with the existence of a program to 'green' oil palm cultivation, but this effort has met with great opposition from the Marind in West Papua. They claim that there is still encroachment on their customary lands. This is because according to Hidayat et al. (2018), due to the Indonesian Sustainable Palm Oil certificate (ISPO) immature implementation coupled with various problems, weak implementing entities and low level of reliability of ISPO to convince the market.

Abdullah et al. (2009) stated the concept of sustainability practiced is to fulfil 3 goals of namely, economic growth, social vitality and ecological integrity. Shehu et al. (2020) perceive the success of Malaysia's palm oil industry in poverty alleviation strategy is due to the sustainability policy adopted by Malaysian Government. Among the things that can be done are good agriculture practice and maintain its biodiversity in oil palm plantation areas Choy, Abdullah \& Zainol (2012). Omar et al. (2016) found, oil palm smallholders in Malaysia, adopt a middleman system. According to Ishak et al. (2016), in order to control these middlemen activities so as not to oppress smallholders, the MPOB as the governing body of Malaysian oil palm has established a systematic formal control mechanism for middlemen. They (middlemen) need to apply for a license. 
RSPO and MSPO as response to critique and debates on the sustainability of palm oil production

MSPO standard, was inaugurated at the end of 2014. Malaysian Palm Oil Certification Council (MPOCC) is an independent organization that sets the rules and procedures for the whole process of MSPO certification. The MPOCC reports to its 13 members, namely the board of trustees that includes government representatives, private sector actors, environmental groups, smallholder groups, academics, and others. As scheme holders, they also act as a secretary for the future review of MSPO standard (Interview with Expert 8, 13 April 2018). Both RSPO and MSPO are established for the common goal to improve agricultural practice and reward actors along the production chain with sustainability certification. The effectiveness of the RSPO, an international association that develops and implements sustainability certification standard for palm oil, has been highly debated in several studies (i.e. Schouten and Glasbergen, 2011; Ruysschaert and Salles, 2014).

RSPO has 8 principles while MSPO has 7 principles. Both certification schemes are $80 \%$ similar and emphasize the sustainable palm oil production where most of the elements revolve around good agriculture practices, sustainable practices concerning environment and social issues. Both certifications contain standard operating procedures with regards to handling chemicals, good working conditions, and ethics. The differences between RSPO and MSPO is that RSPO is a global standard while MSPO is a national standard introduced by the Malaysian government. "As many of the larger plantation companies are leading the way in terms of sustainable practices and the RSPO certification, it is now time to focus on more players to embrace sustainable practices, which includes going through the certification process, especially those left behind in their sustainability journey," ("WWF-Malaysia releases reports", 2018). RSPO set-up is a membership-based scheme, therefore there are certain rules members have to follow. Smallholders with less than 500 hectares of land have to pay Euro 500 per year (RSPO, 2012). RSPO mainly targets major oil palm producers or the "big boys" and largely neglects medium and small companies and smallholders. The cost of attaining RSPO certification also remains prohibitive and the process too onerous for small smallholders. Without substantial injection of subsidies and other forms of assistance from the government it will be difficult for these oil palm producers to get RSPO certified. While RSPO remains the industry standard when it comes to sustainable production of palm oil, only 20 percent of oil palm producers in Malaysia have thus far managed to get certified.

In the beginning, the actors in the palm oil industry were excited and thought that the RSPO certified oil would command a premium price (Rahmat, 2016). Primarily, the RSPO is a global standard for sustainable palm oil production and it claims to be "the world's toughest standard for sustainable agriculture production, which has been variously adapted for other crops" (RSPO, 2012). However, the demand for RSPO-certified oil has been diminishing, which leads to disappointment among certified oil palm growers, particularly after investing substantial time, effort, and money to meet the certification criteria.

Companies that produce RSPO certified palm oil products would have better opportunities to market their output in foreign markets, particularly in the EU states and US markets. Several Malaysian producers found that the RSPO might assist them in penetrating deeper into the European market (Schouten and Glasbergen, 2011). Ruysschaert and Salles (2014) have found some shortcomings of RSPO, which explain the poor outcomes with regards to the protection of the forest area. The RSPO is also vulnerable to inequality in stakeholder representation and lack the capability to resolve conflicts (Schouten and Glasbergen, 2011). Its legitimacy and sustainable standard still need to be improved. As it is a voluntary scheme, RSPO certification therefore will 
be implemented by producers as demanded from customers or buyers. There is no government involvement in RSPO. In the case of conflicts between the parties involved they are required to solve any issues among themselves.

\section{Methodology}

This study employs a qualitative analysis, by which we parse through the transcription of in-depth interviews, relevant documents, and previous literature. Experts were chosen based on their areas of expertise such as agronomy, environmental and bio-economics, public policy making, and public communication. In-depth interviews with oil palm small holders were conducted in person. Small holders are chosen as they are the most vulnerable amongst all actors in the industry.

The empirical data was collected between 13 April 2018 and 20 February 2020. All interviews were recorded, transcribed and analysed thematically to understand the interplay between the governance, actors and policies adopted in Malaysian palm oil industry. In-depth interviews were conducted both in person, skype and via email. Interviews with farmers were conducted by researchers at Yan, Kedah. All statements and verbatim of the experts' interviews are quoted as anonymous. Information on participants are presented in Table 1.

Table 1. Lists of participants

\begin{tabular}{lccc}
\hline No & Participants & Area of Expertise & $\begin{array}{c}\text { Date of } \\
\text { Interview }\end{array}$ \\
\hline 1 & A1 & Agricultural Scientist & 12 March 2019 \\
2 & A2 & Environmentalist, Media \& Communication Expert & 12 March 2019 \\
3 & A3 & Political Scientist & 18 March 2019 \\
4 & A & Bioeconomy Expert & 25 March 2019 \\
5 & A5 & Environmental and Agricultural Economist & 2 April 2019 \\
6 & A6 & Bioeconomy Expert & 11 April 2019 \\
7 & A & Environmental Economist & 13 April 2019 \\
8 & A8 & Policy maker & 13 April 2018 \\
9 & A & Government Agency Officer & 20 February 2020 \\
10 & B 1 & Small holders & 14 March 2019 \\
11 & B 2 & Small holders & 14 March 2019 \\
12 & B 3 & Small holders & 14 March 2019 \\
13 & B 4 & Oil palm plantation & 15 February 2019 \\
\hline
\end{tabular}

\section{Discussion}

How did Malaysian actors push for the MSPO?

The key players in Malaysian palm oil industry urge the Malaysian government to initiate a new certification standard, which allows the authority to control and protect palm oil industry in Malaysia especially from the negative publicity campaigns against palm oil (Azman, 2018). Additionally, an interview with the stakeholder also indicates the importance of MSPO in protecting the local interest of palm oil: 
"As scheme owners we believe decisions by any government entity should be nondiscriminatory... if palm oil gets singled out, it is not fair because there are 16 other vegetable oils"

(Interview with expert 8, 13 April 2018)

A major concern about the RSPO is the price premium, in that the certification would result in higher price due to the increased costs of estate maintenance. There is also a concern amongst the smallholders that their certified crops cannot be sold at a premium price due to lack of demand (Corley, 2018). A careful consideration is needed if the planters are unable to comply with the RSPO requirements, they may be forced to change their business (converting land use to other crops), which will lead to other issues in socio-economic development.

"Small holders, they will be overwhelmed. I don't think so. They maybe because when something conducted on industrial scale, people the farmers will not be able to follow the agreement."

(Interview with Expert 5, 2 April 2018)

Expert 8 had also pointed out that Malaysian Palm oil Industry should be rewarded and not penalized.

"We should be actually rewarded and not penalized. If you take palm oil out of the equation you have to replace it with something else, which will require more areas [...] with higher environmental and social impacts."

(Interview with expert 8, 13 April 2018)

Some small holders did mentioned about the market price and their profit margin.

"Nowadays, the market price effect us. Some of us, quit from planting because they could not afford to pay the workers as they were getting on in age and could not handle such backbreaking work."

(Interview with small holder 1, 14 March 2019)

"I can't get the profit if I employ the workers. Recently the orchard becomes the hangout place for drug addicts."

(Interview with small holder 2, 14 March 2019)

Oil palm plantations that would like to achieve RSPO certification standard may apply for environmental verification and certification schemes, ISO 14001 environmental management system certification, RSPO certification, MSPO and SIRIM Eco-labelling scheme VBB EU also suggested the single certification scheme for palm oil that would be stricter than the RSPO certification. However an expert argued that the single certification as proposed by EU is unrealistic due to long and complex supply chains. As argued by expert:

"European report says they want a single certification scheme, but it is impossible to have one scheme for the whole world; they have to be set nationally"

(Interview with Expert 8, 13 April 2018) 
The MSPO, which targets local planters, is an alternative to the Roundtable on Sustainable Palm Oil (RSPO) standard. MSPO aims to help local planters in gaining more understanding about related law compliance and awareness to protect the environment.

"MSPO certification can help farmers gain more understanding about compliance with law in Malaysia, the importance of sustainability including endangered wildlife, flora and fauna, the environment and even gardeners or organizations to ensure more systematic and sustainable management"

(Interview with expert 9, 20 February 2020)

\section{MSPO and the inclusion of smallholders}

The MSPO was introduced to help mid-range cultivators, who historically could not afford RSPO certification. WWF-Malaysia found that RSPO leads in both system strength and governance and subsections relating to environmental and social strength, while MSPO is not far behind, MSPO biggest problem was related to the chain of custody (records the sequence of custody, control, transfer, analysis, and disposition of evidence). It is due to the absence of a MSPO supply chain certification standard (SCCS) at the time when WWF-Malaysia was conducting its assessment. Since then MSPO has appointed Technical Working Committee to oversee the development of standard setting procedure. WWF-Malaysia then further assesses MSPO using Certification Analysis Tool (CAT) and found that MSPO has scored high in standards section, especially on legality, community relations and biodiversity. However, in the scheme section, chain of custody and agricultural good practices still need major improvement ("WWF-Malaysia releases reports", 2018).

The MSPO standard has four guidelines for actors: the independent smallholders, organized smallholders, plantations, and palm oil mills. The independent smallholders in general hold specific requirements for each principle, while other players - organized smallholders, plantations and palm oil mills - mostly share similar principles. The smallholders' will also under the management of cooperative, mill, estate or dealer, besides MPOB. This group manager will guide all players to ensure enforcement among their members (Senawi et. al, 2019).

The MSPO standard consists of seven principles, which are: i) Management's commitment and responsibility; ii) Transparency; iii) Compliance of legal requirements; iv) Social responsibility, safety and employment conditions; v) Environment, natural resources, biodiversity and ecosystem services; vi) Best practice; and vii) Development of new plantings (Palm Oil Health, 2017). These principles ensures that oil palm production in Malaysia satisfies the need for sustainability and respect for labour rights. Below are the seven principles per elaboration by MPOCC (2019a), MPOCC (2019b), \& MPOCC (2019c).

The first principle requires independent smallholders to apply MSPO policy and have consistent improvement of sustainable palm oil production. They need to be reviewed periodically through internal audit to guarantee MSPO enactment and development plans are in place.

The second principle requires independent smallholders to open their sales and delivery of fresh fruit bunches (FFB) for monitoring by their group management. Traceability also needs to be regularly maintained to ensure transparency in communication and consultation.

The third principle requires all players to comply with applicable laws and regulations. They must respect the Land Use and Customary Land Rights by demonstrating legal ownership. 
In addition, the organized smallholders, plantations and palm oil mills must obey the Free, Prior \& Informed Consent (FPIC) that is in place.

The fourth principle requires all players to include workers' rights to complain and raise grievances and safe work practices with mutually agreed working conditions. The independent smallholders are required to give equally opportunity and treatment provide. Furthermore, if applicable, independent smallholders are required to provide living quarters with basic amenities for their workers. They also must prohibit underage employment or exploitation and the workers' wages must also meet legal standards.

The fifth principle states that independent smallholders are expected to have awareness of environmental impacts, disposal of waste products and sound pollution, with basic understanding of biodiversity and its conservation if necessary. Independent smallholders are also prohibited from practicing open burning either during land preparation or replanting. Independent smallholders should use renewable energy if applicable, which is mandatory for other industry players. Independent smallholders, organized smallholders and plantations are also required to maintain the quality and availability of water resources, while palm oil mills are required to establish water \& waste plan management. All players except independent smallholders need to consult with the Environmental Management Plan (EMP), which includes reduction of pollution that leads to greenhouse effects or global warming.

The sixth principle requires all players to implement best practices in their respective areas of operation. They must demonstrate an economic and financial viability plan that is transparent and fair dealings are encouraged through consultation and communication among the players and other stakeholders.

The seventh principle unequivocally states that there should be no replanting in areas that are steep, fragile and have high biodiversity. Independent smallholders must provide information on soil types and topography for oil palm planting lines. They need to conduct comprehensive Social and Environmental Impact Assessment (SEIA) before commencing new plantings and recognize customary land rights and landowners through Free, Prior and Informed Consent (FPIC).

According to Ministry of Primary Industries, smallholders, specifically in Sarawak, are interested in applying for the MSPO but there are some constraints such as the land conversion issue. As for palm oil industry player, the MSPO is expected to increase cost, which in turn affects the profit margin (Shahida \& Hafizuddin, 2018). According to Kuntom (2018), smallholders feel that MSPO is demanding and burdensome. Among smallholders there is a wide gap between knowledge level and capabilities. Not all smallholders are capable of proving their legal rights to oil palm plantations. There is also the issue of the low production of oil palm fruit bunches production. Smallholders' planting areas are usually not economically optimized. As for small holders, input costs for agricultural activities are also an issue. Malaysian Palm Oil Berhad (2017) reported that government had allocated MYR130 million to smallholders pertaining to the MSPO, which consisted of training cost, audits, personal protective equipment (PPE), and chemical storage shelves. Aziz et al (2016) believe that production will be greater than before once the smallholders commit to MSPO.

Ironically smallholders do not receive much of the information about MSPO. Smallholder 3 , for example, laments the lack of information smallholders have received. The smallholders do not know the status of latest certification scheme although the MSPO standard has been made mandatory by the end of 2019. The following interview reflected the poor information provided to the small holder by the policy makers. 
"Practice certificate, when we registered to MPOC, they (the MPOC) will give us the talk, but as of now, I still haven't received a response (Interview with smallholder 1, 14 March 2019)

"Yes, they said they will call us but until now they don't. They just took the documents and registered it, but until know they haven't called us yet..."

(Interview with smallholder 2, 14 March 2019)

We did ask the independent small holders for their responses and perception with regard to the MSPO. Surprisingly, all of them mention that they have never heard anything on MSPO. The smallholders described:

"No one would come and tell us...no seminars"

(Interview with Small holder 2, 14 March 2019)

"We've already given our phone numbers, they can text us through WhatsApp, we can use it (WhatsApp)"

(Interview with Small holder 1, 14 March, 2019)

At the community level, respondents point out that they should be included in the process of designing the MSPO. They feel marginalized by the policymakers and they are enthusiastic in meeting with the policymakers to share their views (Interview with Small holder 1 and 3, 14 March 2019). However, Interview with Expert 2, 2 April 2019 claimed that Malaysian palm oil industry is built on an industrial scale; hence the small holders will not be able to cope with the agreement. Academics who have relevant expertise are also being left out from the formulation of related policy and national certification scheme. The collaboration between the academia and the industry is important to generate better palm oil policies for the nation (Interview with Expert 7, 13 April 2019).

\section{Implementation of MSPO and Way forward}

The ideas and suggestions of MSPO certification are addressed first by top-level authority before they are developed and investigated by bottom-level agencies that would then focus on research findings and implications (Interview with Expert 7, 13 April 2019). Thus, relevant ministries are directly involved in shaping the sustainable policy in this sector (Interview with Expert 2, 2 April 2019 and Interview with Expert 6, 11 April 2019). An expert pointed out the issues of institutional prerogatives and jurisdictions commonly found within the government:

"Different agencies have different objectives, MPOB on palm oil, LGM on rubber, then there's different ministries overlapping responsibilities, MOA vs MOSTI etc., they are not coordinated"

(Interview with Expert 6, 11 April 2019)

Information gap between federal and local levels and the lack of coordination between various agencies managing the agricultural sector are by no means not the only reasons why the efforts to get domestic palm oil producers certified by MSPO have been lackluster. The federal government must convince the smallholders that MSPO is a better alternative than RSPO. As mentioned by the Interview with Expert 8; 
"So we have to set a bar that is realistic and achievable, a Malaysian bar". Therefore, the government must promote the benefits of good agriculture practices and at the same time raise the bar of MSPO scheme, so it becomes internationally accepted."

\section{Current status of MSPO}

MSPO compliance is mandatory for all players in industry by December 2019 . Until $30^{\text {th }}$ June 2019 , only $42 \%$ of the 5.85 million hectares under oil palm applied for the MSPO certificate (Bernama, 2019a). This includes 2.1 million hectares of plantations and 386,000 hectares of smallholdings, mostly in Kedah, Sarawak and Sabah (Bernama, 2019b). Other than that, 244 palm oil mills and 124 out of the 162 sustainable palm oil clusters (SPOCs) in the country had received the certification, involving 12,000 smallholders and 44,000 hectares of oil palm land. However, until 31st August 2019, the percentage of oil palm land in Malaysia that have MSPO certification increased to $51 \%$ with an additional 44 oil palm mills compared to June 2019 (Bernama, 2019c). Although the implementation of MSPO is mandatory by January 2020, the number of smallholders' applications are too small and do not even achieve 2\% (Kumaran, 2019).

Malaysia government urged the EU to recognize MSPO as one of the voluntary schemes under the Renewable Energy Directive (REDII) since the certification of low indirect land use changes the risk associated with biofuels and bio liquids (Bernama, 2019d). Other international bodies that already recognized MSPO certification are Japanese Olympic Council and the China Green food Development Centre, which has helped Malaysia to market MSPO certified palm oil (Ahmad Daniel, 2019). Malaysia is also committed in making sure that Malaysian palm oil is $100 \%$ MSPO-certified by year 2020 in order to gain the confidence of buyers in the market, especially in the EU (Ismail, 2019).

\section{Conclusion}

\section{Reduce information gap}

Despite the organizational synchronicity between the central (Ministry and MPOB) and state levels (agencies which may closely liaise with the independent smallholders), some crucial information do not make their way down to the local level as evidenced by the gripes of oil palm smallholders in rural Kedah. Such information gap is ironic given the organizational cohesion of the central government and its deep-reaching influence at the local level. For starters, what MSPO can do is to establish a more effective and clearer line of communication between the federal government and the oil palm producers at the local level.

\section{Create awareness campaign and program among small holders}

To ensure the success of MSPO and not to repeat the failure of RSPO in reaching out to the smallholders the federal government needs to create awareness among the smallholders on the importance of getting certified by MSPO. MPOB and related agencies may consider to conduct training and campaign both online and offline to transfer knowledge and create awareness on the importance of MSPO certification scheme. 
Visibility on the importance of MSPO for social and economic impact

The purpose of MSPO certification is for sustainable management of oil palm activities that will benefit not only the environment but also to improve positive social and economic impact while reducing negative impact (Control Union, 2019).. The visibility of the importance of MSPO and its impact to small holders in terms of social and economy will attract more small holders to join the certification scheme.

\section{Leeway on small holder's plantation status}

Until September 2019, there are still a lot of smallholders who have not registered for the MSPO certification. Among the reasons are the smallholders themselves are not comfortable with word 'certification' and they plant the oil palm on land that does not belong to them such as road reserves land that is reserved for roads or to be used to plant rubber or paddy (Mail, 2019).

Efficient monitoring system may capable to increase the number of small holders who obtained the certification. The progress, the challenges of the small holders to full fill the lay out criteria can be figured out hence reducing the risk of not being certified could be lower.

Incentives in replanting old oil palm trees (more than 25 years of lifespan) and to produce value added product

We could see there is improvement in terms of replanting oil palm which have low production rates (more than 25 years old trees). As mentioned earlier the area are reduced from (7.49\%) to $(7.15 \%)$ in 2012 . The future policy to reduce this percentage should be considered to ensure that all oil palm trees are in their productive life span. The old oil palm which are beyond its productive rate (more than 25 years of life span) should be utilize to be use as inputs of other value added product such as particle board panels for biomass.

Merging of the schemes for certification

It may also be beneficial for organized smallholders to work together with FELDA, FELCRA and RISDA in order to apply for certification. Merging the land settlement schemes would pool assets, resources and capacity for certification strategy.

\section{Acknowledgement}

We would like to thank the Fundamental Research Grant Scheme (FRGS) 203.PSOSIAL. 6711783 for supporting this research. We also would like to thank you Janina Puder from University of Jena, Germany who had conducted in-depth interview with Expert 8. 


\section{References}

Abdullah, M. A., Zainol, R. M., Che Rose, R. A., \& Buang, A. (2009). Mengungkap kelestarian pertanian kecil Melayu pada zaman penjajahan British. Geografia-Malaysian Journal of Society and Space, 5(3), 76-87.

Ab Rahman, A. K., Abdullah, R., Mohd Shariff, F., \& Simeh, M. A. (2008). The Malaysian palm oil supply chain: The role of the independent smallholders. Oil Palm Industry Economic Journal, 8(2), 17-27.

Ahmad Daniel, A. N. (2019). MSPO certification essential to ensure long-term future of palm oil. FMT News, October 9. https://www.freemalaysiatoday.com/category/ opinion/2019/ 10/09/mspo-certification-essential-to-ensure-long-term-future-of-palm-oil/

Aziz, M. F. A., Kuntom, A., \& Ibrahim, N. A. N. (2016). Pelaksanaan Skim Pensijilan Minyak Sawit Mampan Malaysia (MSPO) untuk pekebun kecil persendirian di Malaysia. Persidangan Kebangsaan pekebun kecil sawit, 172-176.

Bernama. (2019a). Kok: Only 42 percent of M'sian oil palm achieved MSPO certification. Malaysiakini, August 10. https://www.malaysiakini.com/news/487477

Bernama. (2019b). Over RM100 mil allocated to assist smallholders get MSPO certification. The Edge Market, August 4. https://www.theedgemarkets.com/article/ over-rm100-milallocated-assist-smallholders-get-mspo-certification

Bernama. (2019c). Minister: 51pc oil palm land in M'sia MSPO certified as at Aug 31. Malay Mail, September 21. https://www.malaymail.com/news/money/2019/09/21/minister-51pc-oil-palm-land-in-msia-mspo-certified-as-at-aug-31/1792913

Bernama. (2019d). Malaysia urges EU to recognise MSPO certification. New Straits Times, July 29. https://www.nst.com.my/news/nation/2019/07/508316/malaysia-urges-eu-recognisemspo-certification

Chao, S. (2019). The truth about "sustainable" palm oil. https://www.sapiens.org/culture/palm-oilsustainable/

Che Omar, A. R., Ishak, S., Awang, A. H., Hussain, M. Y., Lyndon, N., \& Othman, A. S. (2016). Orang tengah dalam rantaian pengeluaran pekebun kecil kelapa sawit di Malaysia: Satu penemuan awal di Perak. Geografia-Malaysian Journal of Society and Space, 12(5), 161170.

Ching, O. T. (2017). Mah: Smallholders to get incentives for MSPO certification. New Straits Time, July 27. https://www.nst.com.my/business/2017/07/261457/mah-smallholders-getincentives-mspo-certification

Choy, E. A., Abdullah, M. A., \& Zainol, R. M. (2012). Kemampanan persekitaran kluster sawit: Kajian kes di sekitar Pulau Carey, Selangor. Geografia-Malaysia Journal of Society and Space, 8(8), 121-129.

Control Union. (2019). MSPO-Malaysia Sustainable Palm Oil. https:/certifications.controlunion.com/en/certification-programs/certification-programs/ mspo-malaysia-sustainable-palm-oil

Corley, R. H. V. (2018). Does the RSPO have a future? New Straits Times, November 10. https://www.thestar.com.my/business/business-news/2018/11/10/does-the-rspo-have-afuture

Eco-Business. (2014). Palm oil standard tested for usage by end-2014. The Malaysian Insider, 2014. https://www.eco-business.com/news/palm-oil-standard-tested-usage-end-2014/ 
Hidayat, N. K., Offermans, A., \& Glasbergen, P. (2018). Sustainable palm oil as a public responsibility? On the governance capacity of Indonesian Standard for Sustainable Palm Oil (ISPO). Agric Hum Values, 35, 223-242

Hwei, H. K. S. (2018). Benchmark MSPO against global standards. The Star, October 1. https://www.thestar.com.my/opinion/letters/2018/10/01/benchmark-mspo-against-globalstandards

Ismail, Z. I. (2019). MSPO-certified palm oil to Europe by 2020. New Straits Times, September 17. https://www.nst.com.my/business/2019/09/521977/mspo-certified-palm-oil-europe2020

Ishak, S., Che Omar, A. R., Hussain, M. Y., Awang, A. H., Lyndon, N., Othman, A. S., \& Kasimun, M. S. A. (2016). Menjejaki mekanisme kawalan ke atas aktiviti orang tengah dalam rantaian pengeluaran hasil pekebun kecil kelapa sawit di Malaysia. GeografiaMalaysian Journal of Society and Space, 12(4), 46-58.

Kumaran, S. 2019. The dynamics for mandatory MSPO certification scheme to be successfully implemented. Journal of Oil Palm, Environment \& Health, 10, 1-7. https://doi.org/10.5366/jope.2019.01.

Kuntom, A. 2018. Perlaksanaan dan Cabaran MSPO untuk Pekebun Kecil. Seminar Jawatankuasa Permuafakatan Produktiviti dan Kualiti (JPPK) 2018. http://feldaconference.esteqoma.com/images/Muat_Turun/slaid_JPPK18_Dr-Ainie.pdf

Loh, B. (2018). Roundtable on Sustainable Palm Oil (RSPO) vs Malaysian Sustainable Palm Oil (MSPO); A comparison based on WWF's Certification Assessment Tool (CAT). https://d1kjvfsq8j7onh.cloudfront.net/downloads/rspo_vs_mspo_report_2018.pdf

Mail, R. (2019). Kok: Many independent smallholders in Sarawak still not MSPO-certified. Borneo Post Online, September 18. https://www.theborneopost.com/ 2019/09/18/kokmany-independent-smallholders-in-swak-still-not-mspo-certified/

Malaysia. Malaysian palm Oil Berhad. (2017). Warta Sawit. http://palmoilis.mpob.gov.my/images/wartasawit/6717/files/assets/downloads/page0004. pdf

MPOB. (2019). Malaysian Palm Oil Board. http://www.mpob.gov.my/ index.php?option=com_content $\&$ view $=$ article\&id=1217\&Itemid=322

MPOCC. (2019a). Part 2: General principles for independent smallholders. https://www.mpocc.org.my/part-2-independent-smallholders

MPOCC. (2019b). Part 3: General principles for oil palm plantations and organised smallholders. https://www.mpocc.org.my/part-3-plantations-organised-smallh

MPOCC. (2019c). Part 4: General principles for palm oil mills. https://www.mpocc.org.my/part4-mills

MPOC. (2019). Malaysian Palm Oil Industry. Retrieved from http://www.mpoc.org.my/ Malaysian_Palm_Oil_Industry.aspx.

Palm Oil Health. (2017). What is MSPO certification? https://www. palmoilhealth.org/whatsnew/what-is-mspo-certification/

Azman, F. (2018). Peladang, pekebun perlu ada sijil MSPO, kukuhkan industri minyak sawit Teresa. Astro Awani, December 23. http://www.astroawani.com/berita-malaysia/ peladang-pekebun-perlu-ada-sijil-mspo-kukuhkan-industri-minyak-sawit-teresa-194250

Rahmat, S. R. (2016). Global value chains and the role of innovation for sustainable palm oil an international bioeconomy analysis for Malaysia. Bonn.

RSPO. (2012). Roundtable Sustainable Palm Oil (RSPO). http://www.rspo.org/ 
Ruysschaert, D., \& Salles, D. (2014). Towards global voluntary standards: Questioning the effectiveness in attaining conservation goals: The case of the Roundtable on Sustainable Palm Oil (RSPO). Ecological Economics, 107, 438-446.

Senawi, R., Rahman, N. K., Mansor, N., \& Kuntum, A. (2019). Transformation of palm oil independent smallholders through Malaysian Sustainable Palm Oil. Journal of Oil Palm Research, 31, 496-507. https://doi.org/10.21894/jopr.2019.0038

Schouten, G., \& Glasbergen, P. (2011). Creating legitimacy in global private governance: The case of the Roundtable on Sustainable Palm Oil. Ecological Economics, 70(11), 1891-1899.

Shahida, S., Hafizuddin-Syah, B. A. M., \& Fuad, S. H. (2018). The effect of sustainability certification for export on operational profitability of Malaysian palm oil companies. Jurnal Ekonomi Malaysia, 52(2), 55-67.

Shehu, S., Salleh, M. A., \& Ahmad, A. A. (2020). The sustainable palm oil policies in Malaysia. Journal of Management Theory and Practice, 1(3), 56-60.

SIRIM. (2020). Product Certification. http://www.sirimqas.com.my/index.php/en/ourservices/ sustainability

WWF. (2018). Malaysia releases reports on the comparison between RSPO and MSPO Certification Schemes and assessment of the MSPO Certification Scheme. WWFMalaysia, April 16. http://www.wwf.org.my/?25465\%252FWWF-Malaysia-releasesreports-on-the-comparison-between-RSPO-and-MSPO-Certification-Schemes-andassessment-of-the-MSPO-Certification-Scheme 